PRZEGLĄD NAUK HISTORYCZNYCH 2018, R. XVII, NR 1

http://dx.doi.org/10.18778/1644-857X.17.01.06

AndRZEJ STROYNOWSKI

Akademia im. Jana Deugosza w Czesstochowie*

\title{
Znaczenie alternaty sejmów dla Wielkiego Księstwa Litewskiego w epoce stanisławowskiej
}

W

epoce stanisławowskiej nieprzestrzeganie unijnych zasad alternaty sejmów między Koroną a Wielkim Księstwem Litewskim (WKL) wywoływało protesty reprezentacji litewskiej. Były one w pełni uzasadnione, ponieważ za panowania Stanisława Augusta Poniatowskiego zaledwie dwukrotnie (w latach 1784 i 1793) sejmy obradowały w Grodnie ${ }^{1}$. W dodatku ostatni $z$ nich (1793) tylko formalnie nawiązywał do obowiąującego prawa, ponieważ rzeczywistym powodem zwołania go w Grodnie była chęć uniknięcia nacisku ludności Warszawy, zaangażowanej w obronę zdobyczy Sejmu Czteroletniego. W dodatku marszałkiem sejmu grodzieńskiego został poseł warszawski Stanisław Bieliński, wytypowany do objęcia tej funkcji przez posła rosyjskiego Jakoba Sieversa ${ }^{2}$. Było to oczywiste podważenie zasad alternaty i trudno sądzić, że mogło to zaspokajać ambicje i interesy prowincji litewskiej. Po części tylko warunki te spełniał sejm

* Wydział Filologiczno-Historyczny, Instytut Historii, Zakład Historii Nowożytnej, e-mail: andrzej.stroynowski@gmail.com.

1 Zwołano zaś wówczas 15 sejmów: konwokacyjny, elekcyjny, koronacyjny, zwyczajny 1766 r., nadzwyczajny 1767/1768 r., warszawski 1768 r. (rozszedł się z braku posłów), nadzwyczajny „delegacyjny” w latach 1773-1775, zwyczajny 1776 r., zwyczajny 1778 r., zwyczajny 1780 r., zwyczajny 1782 r., zwyczajny 1784 r., zwyczajny 1786 r., zwyczajny w latach 1788-1792, nadzwyczajny w 1793 r. Por. W. Ko n o p czyńs ki, Chronologia sejmów polskich 1493-1793, Kraków 1948, s. $166-169$.

2 A. Skałkow ski, Stanisław Kostka Bielinski, [w:] Polski słownik biograficzny [dalej: PSB], t. II, Kraków 1936 s. 56-57; Wstęp [do:] J.J. Sievers, Drugi rozbiór Polski z pamiętników, Poznań 1865, s. 10-12. 
warszawski z 1778 r., chociaż po dość burzliwej dyskusji został uznany za „litewski”, czemu jednak przeczyło prowadzenie jego obrad w Warszawie, a nie w Grodnie ${ }^{3}$. Uzasadnieniem „litewskości” tego sejmu miało być obranie posła wileńskiego Ludwika Tyszkiewicza na jego marszałka ${ }^{4}$. Nawet tak połowiczne zastosowanie się do zasad unijnych litewska reprezentacja uznała za swój sukces ${ }^{5}$. Czy jednak takie częśsiowe rozwiązanie problemu alternaty miało rzeczywiste znaczenie? Odpowiedź na takie pytanie w odniesieniu do epoki stanisławowskiej, pomijane w dotychczasowych badaniach, może dostarczyć tylko analiza obrad i dorobku sejmu grodzieńskiego z 1784 r. $^{6}$, jako jedynego, na którym doszło do pełnej realizacji

${ }^{3}$ I. Krzucki, Zdanie... przy podniesieniu laski [5 X 1778], [w:] Zbiór mów różnych w czasie Sejmu ostatniego Sześcio-niedzielnego roku 1778 mianych, Wilno [1778] [dalej: Zbiór mów 1778], nlb. Por. W. Filipczak, Sejm 1778 roku, Warszawa 2000, s. 150; A. Stroy now ski, Opozycja sejmowa w dobie rzadów Rady Nieustającej: studium z dziejów kultury politycznej, Łódź 2005; i d e m, Patriotyczne wystapienia opozycji na sejmie 1778 r., „Acta Universitatis Lodziensis”, Folia Historica 19, 1984, s. 173-180.

${ }^{4}$ Jego wybór był pewnym zaskoczeniem, ponieważ spodziewano się obrania chorażego nadwornego litewskiego Kazimierza Wolmera. Zwycięstwo Tyszkiewicza miało wynikać $z$ jego małżeństwa $z$ Konstancją Poniatowska - bratanicą króla, jak też $z$ faktu, że był jednym $z$ niewielu posłów litewskich, którzy zostali wybrani bez poparcia Antoniego Tyzenhauza. Król do [A.] Tyzenhauza, 14 IX 1778, Archiwum Główne Akt Dawnych w Warszawie [dalej: AGAD], Archiwum Publiczne Potockich [dalej: APP] 310, s. 544; Gazetka pisana z Warszawy, 9 II 1778, Biblioteka Jagiellońska [dalej: BJ], rkps 6799, k. 9; Gazetka pisana z Warszawy, 15 VI 1778, BJ, rkps 6666, k. 458; Gazetka pisana z Warszawy, 25 V 1778, B. PAN, rkps 993, k. 152; Gazetka pisana z Warszawy, 14 IX 1778, Biblioteka Polskiej Akademii Nauk w Krakowie [dalej: B. PAN], rkps 993, k. 185; Gazetka pisana z Warszawy, 19 IX 1778, B. PAN, rkps 993, k. 187; W. Fili pczak, Sejm 1778 roku..., s. 40-41, 144-145; Anegdoty $i$ sensacje obyczajowe wieku Oświecenia w Polsce. Dokumenty, wspomnienia, facecje, zebrał i oprac. R. Kaleta, Warszawa 1958, s. 30, 291.

${ }^{5}$ „Winszować mi sobie także należy jako Obywatelowi i Posłowi z Prowincji WXLit. że podniesienie laski przez też Prowincję zawsze sławnym i Polszcze nader miłym jest...”. K. [N.] Sa pie ha, Mowa (...) 6 X 1778, [w:] Zbiór mów 1778, nlb.

${ }^{6}$ A. Stroy now ski, Opozycja sejmowa..., s. 169-180; id e m, Sklikanne pershaga pry Stanislavu Ay̆gustu Panjatoy̆skim sojma y̆ Goradni y̆ 1784 godze, „Arche”, Garadzenski milenium 2014, № 11, s. 251-274; id e m, Sojm u Gorodni y̆ 1784 g. Ab'jawnanyja pasjadżenni palat 6-23 kastrychnika 1784 g., „Arche”, Garadskaja gistoryja Belarusi 2017, № 2 (152), s. 199-224. Pozostałe sejmy stanisławowskie, nawet obradujace w Grodnie lub mające za marszałków reprezentantów Litwy, nie spełniały tych warunków, jak wskazano to już w odniesieniu do obradujacych w 1778 i 1793 r. Jeszcze wyraźniejsze jest to w odniesieniu do sejmu elekcyjnego 1764 r., kierowanego przez posła brzeskolitewskiego Józefa Sosnowskiego, jak też sejmu delegacyjnego 1767/1768 r., którego marszałkiem był Karol Stanisław Radziwiłł (jako marszałek konfederacji generalnej koronnej). Z. Zi elińska, Sosnowski Józef Sylwester, [w:] PSB, t. XL, Warszawa-Kraków 2001, s. 559-563; 
zasad alternaty, czyli prowadzenia obrad w Grodnie i pod przewodnictwem marszałka wybranego spośród posłów litewskich ${ }^{7}$.

Skupienie uwagi tylko na tym sejmie jest uzasadnione również jego wyjątkowym miejscem w dziejach parlamentaryzmu epoki stanisławowskiej. Wyróżniał się on swoim dorobkiem ustawodawczym na tle pozostałych sejmów zwyczajnych $z$ lat $1778-1786^{8}$, powszechnie uznawanych za "jałowe" 9 . Dla oceny znaczenia tego sejmu dla społeczeństwa litewskiego konieczne jest zwłaszcza dokonanie analizy przejawów aktywności parlamentarnej ${ }^{10}$, jak też dorobku ustawodawczego tegoż sejmu ${ }^{11}$. W tym szczególnego znaczenia nabiera

J. Michals ki, Radziwiłt Karol Stanisław, [w:] PSB, t. XXX, Wrocław 1987, s. 253. W dodatku sejmy obradujące pod węzłem konfederacji były uznawane przez społeczeństwo litewskie za zagrożenie dla swojej odrębności, jako realizujące ideę scentralizowanej władzy państwowej bez odwołania się do unijnych zasad. A. Kalenkiewiczówna, Rozkład partii Tyzenhauza na tle sejmików litewskich, [w:] Księga pamiatkowa Koła Historyków Słuchaczy Uniwersytetu Stefana Batorego w Wilnie 1923-1933, Wilno 1933, s. 152-186; J. Male c, Szkice z dziejów federalizmu i myśli federalistycznej $w$ czasach nowożytnych, Kraków 1999, s. 57-69.

7 W. Kon o p czyńs ki, Chomiński Franciszek Ksawery, [w:] PSB, t. III, Kraków 1937, s. 416-417.

${ }^{8}$ Dla porównania: na sejmie 1778 r. przyjęto 32 konstytucje, podobnie jak w roku 1786, podczas gdy w 1782 r. było to zaledwie 10 konstytucji. W. Filipczak, Sejm 1778 roku..., s. 335; J. Sobczak, Położenie prawne ludności tatarskiej $w$ Wielkim Księstwie Litewskim, Warszawa-Poznań 1984, s. 107. Terminu „konstytucje” używam tutaj w rozumieniu osiemnastowiecznym. S. Grodziski, Sejm dawnej Rzeczypospolitej jako najwyższy organ ustawodawczy. Konstytucje sejmowe - pojęcia i próba systematyki, „Czasopismo Prawno-Historyczne” 1983, t. XXXV, z. 1, s. 172 .

${ }_{9}$ W. Filipczak, Sejm Rzeczypospolitej $w$ dobie stanisławowskiej, [w:] Miedzy konstytucja Nihil Novi a ustawodawstwem nowoczesnej demokracji. Parlamentaryzm polski XVI-XX wieku. Materiały Ogólnopolskiej Konferencji Naukowej odbytej w Radomiu w dniach 12-13 października 2005 roku, red. H. Gmiterek, S. Piątkowski, J. Wrona, Radom 2005, s. 59-82; id e m, Uwagi o funkcjonowaniu „wolnych" sejmów okresu Rady Nieustajacej (1778-1786), [w:] Parlamentaryzm w Polsce we współczesnej historiografii, red. J. Bardach, W. Sudnik, Warszawa 1995, s. 122; A. Stroynowski, Opozycja sejmowa..., s. 12; Z. Zielińska, Sejmy polskie z lat 1764-1786, [w:] Parlamentaryzm w Polsce..., s. 113-114.

10 Wyrażała się ona w jego mowach, zagajeniach, podejmowaniu inicjatywy ustawodawczej, zarządzaniu głosowaniami i ogólnym kierowaniu obradami. Podstawą źródłowa do analizy jego aktywności stanowi: Dyariusz sejmu wolnego ordynaryjnego grodzieńskiego sześcioniedzielnego Roku Pańskiego MDCCLXXXIV dnia 4 miesiaca października odprawującego się, [wyd. M. Tukalski-Nielubowicz], Warszawa 1785 [dalej: Diariusz sejmu 1784]; Dyaryusz tygodniowy sejmu... MDCCLXXXIV, b.m.d. [dalej: Diariusz tygodniowy 1784]; Zbiór mów w czasie sejmu sześcioniedzielnego roku 1784 mianych $w$ Grodnie, Wilno [po XI 1784] [dalej: Zbiór mów 1784].

${ }^{11}$ Przyjęto wówczas 46 konstytucji, zajmujacych aż 22 strony w Zbiorze Praw, Volumina legum [dalej: Vol. leg.], t. IX, Kraków 1889, s. 7-29. 
ocena postawy marszałka Franciszka Ksawerego Chomińskiego, przede wszystkim jego zaangażowanie w obronę interesów Wielkiego Księstwa Litewskiego.

$Z$ reguły wydaje się, że kwestia miejsca obrad sejmu nie miała specjalnego znaczenia. Jednak w odniesieniu do społeczeństwa litewskiego żądania przestrzegania alternaty Warszawy i Grodna było uzasadnione nie tylko patriotyzmem lokalnym, wyrażającym się w częstym przypominaniu, że sejm na Litwie po raz ostatni obradował w 1752 r. ${ }^{12}$ Doprowadzenie do odbycia tego sejmu w Grodnie przyniosło bowiem znaczne korzyści społeczeństwu Wielkiego Księstwa Litewskiego, zwłaszcza jego reprezentacji sejmowej, która zyskała możliwość wystapienia w roli gospodarza, co miało zaowocować chociażby pełniejszym zaprezentowaniem swojego stanowiska wobec najważniejszych problemów całego państwa. Zmuszono też Stanisława Augusta do odbycia pierwszej podróży na Litwę, potraktowanej zreszta przez władce jako element przedsejmowej propagandy, ale też łączonej $z$ dążeniem do umacniania swojej pozycji w Wielkim Księstwie ${ }^{13}$. Dlatego też, już w trakcie sejmowych obrad, przypomniał on sobie o miejscu swoich narodzin - Wołczy$n^{14}{ }^{14}$. Nie tylko prestiżowe korzyści odnieśli też czołowi magnaci litewscy, którzy mogli gościć u siebie władcę, zmuszonego do szukania poparcia u niezbyt mu przychylnych Karola Stanisława Radziwiłła i Michała Kazimierza Ogińskiego. „Panie Kochanku” zreszta liczył na królewskie wsparcie w staraniach o uzyskanie 4 mln złp. $z$ tytułu wyrównania strat $z$ czasów emigracji ${ }^{15}$. Najważ-

${ }^{12}$ W. Konopczyńs ki, Chronologia sejmów polskich..., s. 39; A. Stroynows ki, Opozycja sejmowa..., s. 172-173; id e m, Problem odrębności litewskiej w obradach sejmów lat 1778-1786, [w:] Rzeczpospolita państwem wielu narodowości i wyznań XVI-XVIII wiek, red. T. Ciesielski, A. Filipczak-Kocur, Warszawa-Opole 2008, s. 125-141; i d e m, Sklikannie perszawa pry Stanislawu Awgustu Poniatowskim sojma..., s. 251-274.

${ }^{13}$ Monarcha odwiedził m.in. Białowieżę, Pińsk, Różany i Szczorse, chociaż główne znaczenie miał pobyt u „Panie Kochanku” w Nieświeżu. [A. Naruszew i c z], Dyaryusz podróży... Stanisława Augusta na Seym Grodzieński..., Warszawa 1784; A.S. Naruszewicz, Dyjaryjusz podróży Jego Królewskiej Mości na sejm grodzieński, wyd. M. Bober-Jankowska, Warszawa 2008; K. Bartoszewicz, Radziwiłłowie, Warszawa-Kraków 1927, s. 152-156; D. Rolnik, Miejsce i rola Radziwiłłów w życiu publicznym Rzeczypospolitej lat 1764-1795 w świetle literatury pamiętnikarskiej czasów stanisławowskich, [w:] Radziwiłłowie. Biografie. Świadectwa historyczne, red. K. Steppnik, Lublin 2003, s. 393.

${ }^{14}$ [Stanisław August Poniatowski], Mowa (...) przed rozłaczeniem izb (...) $23 \times 1784$, [w:] Zbiór mów 1784, s. 80 .

${ }_{15}$ Z. Anusik, A. Stroy now s ki, Problemy majątkowe Radziwitłów w XVIII w., „Roczniki Dziejów Społecznych i Gospodarczych” 1987, t. XLVIII, s. 94; K. Bar- 
niejsze jednak znaczenie miało przynajmniej oficjalne wycofanie się monarchy $z$ forsowania unifikacji i podważania jego unijnego charakteru państwa, wyrażającego się chociażby w alternacie miejsca obrad sejmu (Warszawa i Grodno) ${ }^{16}$.

Przy okazji zdołano też przełamać królewską niechęć do samego Grodna, które bardzo źle wspominał od czasu swojego udziału w sejmie 1752 r. ${ }^{17}$ Dzięki obradom sejmu miasto, znane $z$ bardzo trudnych warunków zakwaterowania i z wręcz niebywałej drożyzny, mogło spodziewać się sporych korzyści ${ }^{18}$. Szczególnie zatrważający obraz miasta kreślili cudzoziemcy ${ }^{19}$. Trzeba przyznać, że opinie te musiały odpowiadać prawdzie, skoro według spisu z $1789 \mathrm{r}$.

toszewicz, op. cit., s. 236; J. Iwaszkiewicz, $Z$ dziejów wielkiej fortuny, „Biblioteka Warszawska” 1911, R. IV, s. 479-501; J. Micha1ski, Radziwiłt Karol Stanisław..., s. 259; J. Mycielski, Ksią̇e „Panie Kochanku” w świetle własnej korespondencji, Petersburg 1989, s. 112. Należy jednak pamiętać, że sprawa Tyzenhauza ciagle nie była rozwiazana, podobnie jak i dania absolutorium (kwitu) dla Komisji Skarbowej Litewskiej, która po raz ostatni została pozytywnie zweryfikowana w $1778 \mathrm{r}$.

16 „Król, zwolennik modelu nowoczesnego państwa, rządzonego jednolitym prawem, uważał dualizm państwowy Rzeczypospolitej za anachronizm, czemu dawał niejednokrotnie wyraz". J. Bardach, Konstytucja 3 Maja i Zaręczenie Wzajemne Obojga Narodów 1791 roku, [w:] Konstytucja 3 Maja 1791, Warszawa 2001, s. 56. Dla realizacji tej koncepcji król zaryzykował nawet niepowodzenie programu reform, podjętych już na Sejmie Czteroletnim. A. Sulima Kamiński, Historia Rzeczypospolitej wielu narodów 1505-1795. Obywatele, ich państwa, kultura, Lublin 2000, s. 237. Por. J. B ard a ch, O Rzeczpospolita Obojga Narodów. Dzieje związku Polski z Litwa do schyłku XVIII wieku, Warszawa 1998, s. 18, 41; J. Malec, Próby ściślejszego zespolenia Litwy z Korona $w$ latach 1764 1786, „Lituano-Slavica Posnaniensia. Studia Historia” 1987, t. II, s. 181; A.B. Zakrzewski, Paradoksy unifikacji prawa $i$ ustroju Wielkiego Ksiestwa Litewskiego i Korony XVI-XVIII w., „Czasopismo Prawno-Historyczne” 1999, t. LI, z. 1, s. 223-224.

${ }_{17} \mathrm{~W}$ spisanych później pamiętnikach pisał, że wówczas w Grodnie, oprócz zamku królewskiego, stały tylko dwa murowane budynki, podczas gdy reszta była drewniana i bardzo niestarannie wzniesiona. Stanisław August Poniatows ki, Pamiętniki, oprac. Z. Góralski, t. I, Warszawa 1994.

18 Symptomatyczne sa tu zabiegi kasztelana bracławskiego Marcina Grocholskiego, który już w lutym 1784 r., jeszcze przed oficjalna decyzją wyznaczenia Grodna na miejsce obrad sejmu, rozpoczą starania o znalezienie odpowiedniego lokum. M. Grocholski do NN, 1 II 1784, Biblioteka Czartoryskich w Krakowie [dalej: B. Czart.] 726, s. 401.

19 W. Coxe, Podróż po Polsce, [w:] Polska stanisławowska w oczach cudzoziemców, oprac. W. Zawadzki, t. I, Warszawa 1963, s. 683-684; G. Forster, Dziennik podróży po Polsce, [w:] ibidem, t. II, s. 77-78. Brak miejsc noclegowych był zreszta stałym problemem Grodna, co w 1678 r. zrodziło nawet pomysł przeniesienia obrad sejmowych do innego miasta. K. Matwijowski, Sejm grodzieński 1678-1679, Wrocław 1985, s. 72-73. 
Grodno liczyło tylko 5653 mieszkańców i 1014 domów ${ }^{20}$. Natomiast same warunki obrad w tzw. Nowym Zamku, wzniesionym w latach 1737-1742, były poprawne, o czym swiadczy skromny zakres zaplanowanych remontów i przygotowania części mieszkalnej, który według podskarbiego nadwornego litewskiego Antoniego Dziekońskiego nie wymagał nadzwyczajnego zwiększenia środków przez Radę Nieustającą ${ }^{21}$. Niewątpliwie jednak obrady sejmu musiały przynieść poprawę stanu zamku, jak też zapewnić nadzwyczajne dochody mieszkańcom miasta.

W tej sytuacji nie może dziwić, że przynajmniej od 1780 r. reprezentacja litewska ponawiała żądania zwołania sejmu do Grodna. $Z$ hasłem tym po raz pierwszy - w imieniu sesji prowincjonalnej litewskiej - wystapił poseł lidzki Józef Narbutt ${ }^{22}$, na kolejnym zaś posłowie: słonimski Michał Szwykowski ${ }^{23}$, wileński Adam Kazimierz Czartoryski $^{24}$ i brzeskolitewski Stanisław Ursyn Niemcewicz ${ }^{25}$.

20 J. Gordziejew, Socjotopografia Grodna w XVIII wieku, Toruń 2009, s. 250. Zauważmy, że są to dane bardzo zbliżone do nieco późniejszego spisu z 1817 r., który wykazał 5091 mieszkańców (w tym 3212 ludności żydowskiej). Wówczas zabudowania miejskie obejmowały 1109 domów (w tym 284 murowanych). Słownik Geograficzny Królestwa Polskiego i innych krajów słowiańskich, red. F. Sulimierski, B. Chlebowski, W. Walewski, t. II, Warszawa 1881, s. 831.

${ }^{21}$ Protokół Rady Nieustającej z 4 V 1784, AGAD, Metryka Litewska VII/52, k. 4v; A. Dziekoński do króla, 5, 12 i 16 VI 1783, B. Czart. 661, s. 289-290, 301; W. Kri g g e is en, Sejm Rzeczypospolitej szlacheckiej (do 1763 roku). Geneza i kryzys władzy ustawodawczej, Warszawa 1995, s. 178.

22 „Prowincja Litewska od dawnego już czasu traci na pożytkach swego Przywileju, że nie ma alternaty Seymów, Prawem Kardynalnym Unii jak najuroczyściey zabezpieczoney [...] Kilkadziesiąt lat upłynnionych liczemy, jak Prześwietne Prowincje Koronne tego warunku w Prawie Kardynalnym Unii opisanego nie dotrzymują [...] Niech Unia czczym tylko słowem, y próżno brzmiącym nie będzie dźwiękiem". Sesja XXIX i XXX dnia 5 i 6 XI 1780, Dyaryusz sejmu wolnego ordynaryjnego warszawskiego sześcioniedzielnego Roku Pańskiego MDCCLXXX dnia 2 miesiąca października odprawuiącego się, [wyd. S. Badeni], Warszawa [1780], s. 416, 443-444.

${ }^{23}$ Michał Szwykowski prócz tego potępiał obciażanie Litwy połowa kosztów utrzymania władz centralnych, gdy powinny one być dzielone między trzy prowincje. Sesja XVIII dnia 19 X 1782, Dyaryusz sejmu wolnego ordynaryjnego warszawskiego sześcioniedzielnego Roku Pańskiego MDCCLXXXII, [P. Kicińskiego], [Warszawa 1782], [dalej: Diariusz sejmu 1782], s. 118-119.

${ }^{24}$ Sesja XVIII dnia 19 X 1782, Diariusz sejmu 1782, s. 120. W kolejnym wystapieniu wyraził zgodę na dokonanie wyboru miejsca obrad przyszłego sejmu między Grodnem a Wilnem. Sesja XXXI dnia 4 XI 1782, Diariusz sejmu 1782, s. 394.

${ }^{25}$ Po ostrej mowie w obronie uwięzionego biskupa Kajetana Sołtyka „najpokorniej” prosił o zwołanie kolejnego sejmu na Litwie, stosownie do wcześniejszych głosów Szwykowskiego i Czartoryskiego. Sesja XIX dnia 21 X, Diariusz sejmu 1782, s. 169. 
O ile kwestia miejsca obrad może wydawać się mniej istotna, o tyle zasadnicze znaczenie mogło mieć zdobycie funkcji marszał$\mathrm{ka}$, będacego reprezentantem swojej prowincji i rodzimego regio$n u^{26}$. Zdobycie laski marszałkowskiej zdawało się zapewniać większe możliwości wpływania na przebieg i wynik obrad sejmu ${ }^{27}$. Przekonanie to wyrażało się $\mathrm{w}$ tak usilnych zabiegach o zostanie marszałkiem przez ambitnych posłów ${ }^{28}$, jak też króla i przywódców ugrupowań politycznych ${ }^{29}$. Wybór odpowiedniego marszałka zależał też od zadań, które przed nim stawiała sytuacja wewnętrzna i międzynarodowa. Jednak w 1784 r. nie było żadnych zagrożeń na arenie międzynarodowej wobec pokojowego przeprowadzenia aneksji Krymu przez Rosję 18 lutego 1784 r. ${ }^{30}$, nie było także nadziei na realizację królewskich planów reformatorskich bazujących na Rosji, która nie zgadzała się na skonfederowanie sejmu ${ }^{31}$. Wobec

${ }^{26}$ Wiąało się to $z$ wyraźnym traktowaniem funkcji politycznych, szczególnie zaś poselskich, za ściśle związane $z$ regionem, $z$ wyborcami. A. Stroy now ski, Poset - reprezentant narodu, czy regionu? Ujęcie historyczne, [w:] Oblicze polityczne regionów Polski. Elity i społeczeństwo, red. M. Dajnowicz, Białystok 2008, s. 237-251.

27 A. Stroynowski, Wpływ marszałków na obrady sejmów stanisławowskich, [w:] idem, "Wieczory sejmowe”. Studia nad dziejami parlamentaryzmu $w$ epoce stanisławowskiej, Częstochowa 2013, s. 103-118. Por. Historia sejmu polskiego, t. I (Do schyłku Rzeczypospolitej), red. J. Michalski, Warszawa 1984; R. Łaszewski, Sejm polski w latach 1764-1793. Studium historyczno-prawne, Warszawa 1973; W. Krieg s e is e n, op. cit.; H. Ols zew ski, Wstep, [do:] Marszatkowie sejmów I Rzeczypospolitej, oprac. W. Sieradzki, J. Kotowicz, J. Walukiewicz-Wolfram, Warszawa 1993, s. 5-23; A. R a c hu ba, Litewscy marszałkowie sejmów Rzeczypospolitej (1569-1793), [w:] Kultura parlamentarna epoki staropolskiej. Studia pod redakcja Andrzeja Stroynowskiego, Warszawa 2012, s. 33-47.

${ }^{28}$ Dla zdobycia tej funkcji 16 VI 1788 r. Stanisław Szczęsny Potocki nawet zrezygnował $z$ urzędu wojewody ruskiego, co jednak nie dało mu upragnionej laski, która przeją Stanisław Małachowski. W. Kalinka, Sejm Czteroletni, t. I, Kraków 1895, s. 105, 117, 121; E. Ros tworowski, Potocki Stanisław Szczęsny, [w:] PSB, t. XXVIII, Wrocław 1984, s. 187.

${ }^{29}$ O kolejnych bataliach na sejmach stanisławowskich szerzej: A. Stroy nowski, Opozycja sejmowa...

${ }^{30}$ T. Srogos z, Rzeczpospolita wobec aneksji Krymu przez Rosję w 1783 roku, [w:] Władza i polityka w czasach nowożytnych, red. Z. Anusik, Łódź 2011, s. 77-96; id e m, Dywizja ukrainska i podolska wobec wkroczenia armii rosyjskiej do Rzeczypospolitej w 1783 roku, „Naukovi praci istorichnogo fakultetu Zaporizkogo nacionalnogo universitetu" 2009, Vipusk 26, s. 133-137. Por. Historia dyplomacji polskiej, t. II (1572-1795), red. Z. Wójcik, Warszawa 1982, s. 571; W. Kon opczyńs ki, Fryderyk Wielki a Polska, Poznań 1947, s. 253-257.

${ }^{31}$ Gazeta pisana $z$ Warszawy, 12 I 1784, Biblioteka Kórnicka PAN [dalej: BKPAN], rkps 1331, k. 4; Gazeta pisana z Warszawy, 7 VIII 1784, BKPAN, rkps 1330, k. 52; J. Michalski, Sprawa przymierza polsko-rosyjskiego $w$ dobie 
rezygnacji króla $z$ podejmowania poważniejszych reform doszło też do uspokojenia nastrojów wewnątrz kraju, czemu sprzyjało osłabienie opozycji po śmierci (12 sierpnia 1783) marszałka wielkiego koronnego Stanisława Lubomirskiego ${ }^{32}$. Pozycje monarchy umocniły także nominacje na najwyższe urzędy członków swojej rodziny: Michała i Stanisława Poniatowskich oraz Michała Wandalina Mniszcha $^{33}$. W rezultacie na sejmie nie należało oczekiwać większych sporów i rzeczywistym jego celem miało być tylko przeprowadzenie uchwały o spłacie długów królewskich, co zdawało się gwarantować pełne zwycięstwo na przedsejmowych sejmikach poselskich ${ }^{34}$. Pozostawała jednak kwestia wyboru odpowiedniego marszałka spośród posłów litewskich.

aneksji Krymu, [w:] idem, Studia historyczne z XVIII i XIX wieku, t. I (Polityka i społeczeństwo), Warszawa 2007, s. 420-448.

32 J. Michalski, Lubomirski Stanisław, [w:] PSB, t. XVIII, Wrocław 1973, s. 56; A. Stroynowski, Zmiany sytuacji politycznej $w$ Rzeczypospolitej przed ostatnim „wolnym” sejmem w 1786 r., "Acta Universitatis Lodziensis”, Folia Historica 58, 1996, s. 91; id e m, Opozycja sejmowa..., s. 55-58.

${ }^{33}$ B. Zaleski, Korespondencja krajowa Stanisława Augusta z lat 1784 do 1792, Poznań 1872, s. 21; Z. Zielińska, Poniatowski Michał Jerzy, [w:] PSB, t. XXVII, Wrocław 1982, s. 457; J. Michalski, Poniatowski Stanisław, [w:] PSB, t. XXVII, Wrocław 1982, s. 481-487; A. Rosner, Mniszech Michat Jerzy Wandalin, [w:] PSB, t. XXI, Wrocław 1976, s. 480-484. Por. W. Filipczak, Życie sejmikowe prowincji wielkopolskiej w latach 1780-1786, Łódź 2012, s. 111-112; A. Stroy now ski, Postawy polityczne elit Wielkopolski w epoce stanisławowskiej (województwa poznańskie, kaliskie i gnieźnieńskie), [w:] Między barokiem a oświeceniem. Staropolski regionalizm, red. S. Achremczyk, Olsztyn 2008, s. 203-214; id e m, Elita polityczna Wielkopolski w epoce stanisławowskiej, [w:] Spojrzenia na pogranicze dawniej i dziś. Budowanie tożsamości na pograniczach, red. B. Burda, M. Szymczak, cz. 1, Zielona Góra 2009, s. 70-84.

${ }^{34} \mathrm{O}$ braku innych zadań sejmu świadczyły już uniwersały przedsejmowe $20 \mathrm{~V}$ 1784 r. oraz „propozycje od tronu”, ograniczone do dziewięciu tylko punktów. Diariusz sejmu 1784, s. 3; Diariusz tygodniowy 1784, s. 42-47; Propozycje od tronu... na sejm 1784, b.m.d.; Gazeta pisana $z$ Warszawy, 28 VIII 1784, BKPAN, rkps 1331, k. 60; Król do Debolego, 21 VIII 1784, AGAD, Archiwum Królestwa Polskiego [dalej: AKP] 268, k. 114; A. Stroy now ski, Opozycja sejmowa..., s. 172-173, 179; idem, Sklikanne pershaga pry Stanislavu Ay̆gustu Panjatoy̆skim sojma..., s. 251-274; W. Konopczyński, Chronologia sejmów polskich..., s. 39. Por. A. Lityński, Sejmiki ziemskie 1764-1793, Katowice 1988; R. Łaszewski, Pozycja sejmików przedsejmowych w systemie politycznym Polski stanisławowskiej, [w:] Ustrój $i$ prawo $w$ przeszłości dalszej $i$ bliższej. Studia o prawie dedykowane Prof. Stanisławowi Grodziskiemu w pięćdziesiąta rocznice pracy naukowej, red. J. Malec, W. Uruszczak, Kraków 2001, s. 139-144; A. Stroynowski, Przeprowadzenie spłaty długów królewskich na sejmie 1784 roku, [w:] Sic erat in votes. Studia i szkice ofiarowane Profesorowi Zbigniewowi Anusikowi w sześćdziesiata. 
Wybór padł na posła pińskiego Franciszka Ksawerego Chomińskiego (urodzonego ok. 1735 r.), syna skromnego chorążego oszmiańskiego Hilarego i Anny z Kopciów. Franciszek Ksawery edukację i pierwsze stopnie kariery zdobył u Radziwiłłów. W 1764 r. związał się $z$ Familia, co dało mu awans na pułkownika i możliwość zbliżenia się do Michała Kazimierza Ogińskiego. Wraz z nim znalazł się w konfederacji barskiej i wziął udział w przegranej bitwie pod Stołowiczami 23 września $1771 \mathrm{r} .{ }^{35}$ Po powrocie $z$ emigracji Chomiński prowadził interesy Ogińskiego, chociaż powierzony jego opiece majątek wykorzystywał w celu bogacenia się ${ }^{36}$. Jednocześnie zaczął szukać możliwości zbliżenia się do króla Stanisława Augusta Poniatowskiego, chociaż dopiero w 1780 r. uzyskał jego poparcie w staraniach o poselstwo, stajacc się najaktywniejszym mówca tego sejmu ${ }^{37}$. Na kolejnym sejmie był już mniej aktywny, zręcznie unikajac wypowiadania się w spornych kwestiach, co dało mu Order Świętego Stanisława ${ }^{38}$. Jednocześnie zdobywał coraz większą popularność wśród szlachty pińskiej jako starosta i gościnny gospodarz ${ }^{39}$. Najważniejsze jednak było zdobycie pozycji kompromisowego polityka, popieranego zarówno przez opozycyjnych magnatów litewskich, jak i króla, który mógł wykorzystać go do budowania stronnictwa dworskiego, opierającego się na średniej szlachcie $^{40}$. Dla władcy jednak najważniejsze było jego doświadcze-

rocznice urodzin. Rzeczpospolita w czasach nowożytnych, red. M. Karkocha, P. Robak, Łódź 2017, s. 363-383.

${ }^{35} \mathrm{Z}$ czasem to głównie Chomińskiemu przypisywano winę za tę klęskę, gdyż nie mając żadnego doświadczenia wojskowego ani talentu, wpływał na decyzje hetmana. J.U. Niemcewicz, Pamiętniki czasów moich, wyd. J. Dihm, t. I, Warszawa 1957, s. 111; W. Kon opczyń ski, Chomiński Franciszek Ksawery..., s. 416-417.

${ }^{36}$ Zagadki Sejmu Czteroletniego, zebrał E. Rabowicz, oprac. B. Krakowski, E. Rabowicz, wyd. J. Kowecki, Warszawa 1996, s. 51.

${ }^{37}$ Zapowiedź poparcia swojej kandydatury uzyskał już w 1778 r. W. Filipczak, Sejm 1778 roku..., s. 50.

${ }^{38}$ Diariusz sejmu 1782; Zbiór mów różnych $w$ czasie sejmu sześcioniedzielnego sejmu roku 1782 mianych, Wilno [1782]; A. Stroy n ow ski, Opozycja sejmowa..., s. 158-165, 470; Z. Dunin-Wilczyński, Order Św. Stanisława, Warszawa 2006, s. 189.

39 Utrzymywał „[...] stół otwarty w Pińsku; stół smaczny i wykwintny był jedna z przedniejszych pasji jego”. J.U. Niemcewicz, op. cit., t. I, s. 111; W. Konopczyńs ki, Chomiński Franciszek Ksawery..., s. 416.

40 W. Filipczak, Sejm 1778 roku..., s. 100, 103. Nie było też innej kandydatury do laski marszałkowskiej, ponieważ już wiosna zrezygnował z ubiegania się 
nie wojskowe, administracyjne i parlamentarne, pozwalajace wierzyć, że zdoła on sprawnie pokierować obradami i przeprowadzić królewskie propozycje ${ }^{41}$. Jako kompromisowy kandydat zyskał też powszechne poparcie posłów prowincji litewskiej, życzących mu, aby „[...] tę Alternatę sejmu $z$ chwałą dla siebie, a dla Narodu, uczynisz pożyteczna" 42 i w rezultacie już 4 października 1784 r. został wybrany marszałkiem sejmu ${ }^{43}$.

Zgodnie $z$ ogólnymi założeniami miał głównie starać się o maksymalne przyspieszanie tempa obrad, chociażby forsując rezygnację ze zwyczajowych podziękowań królowi za uzyskane nominacje ${ }^{44}$. Stale też dążył do łagodzenia sporów i tylko czasem ujawniał swoją szczególna sympatię dla reprezentantów Wielkiego Księstwa. Tak chociażby było w momencie wysunięcia przez posła krakowskiego Szymona Michalczewskiego zarzutu wobec biskupa Stefana Giedroycia o nieprawne posługiwanie się tytułem ksiażęcym. Zarzut ten wywołał wręcz „rumor”, ale Chomińskiemu udało się przerwać spór zapowiedzią późniejszego powrócenia do tej kwestii ${ }^{45}$.

W pierwszym okresie obrad sejmowych, czyli prowadzonych wspólnie $z$ senatem i królem, możliwość wpływania marszałka na przebieg sejmu był nieco ograniczony. Chomińskiemu udało się jednak, przy niewattpliwym poparciu króla, doprowadzić do pomyślnego pokierowania dyskusja nad zakwitowaniem (udzieleniem absolutorium) Komisji Skarbowej Litewskiej i ściśle $z$ tym związaną kwestią odpowiedzialności byłego podskarbiego Antoniego Tyzenhauza. Tu stanał przed koniecznością połączenia rozbieżnych interesów politycznych (władcy i opozycji), jak też lokalnych, ponieważ Tyzenhauz był zwalczany przez część reprezentacji litewskiej. Pojawiła się też tendencja reprezentantów Wielkiego Księstwa Litewskiego do

o nią Kazimierz Nestor Sapieha. Król do A. Debolego, 17 III 1784, AGAD, AKP 268, k. 45; K.N. Sapieha do K.S. Radziwiłła, 3 IV 1784, AGAD, Archiwum Radziwiłłowskie V/13850.

${ }^{41}$ [Stanisław August Poniatowski], Mowa... przed rozłaczeniem izb... 23 X 1784, [w:] Zbiór mów 1784, s. 71, 80. Ze szczególnym entuzjazmem o umiejętnościach Chomińskiego w zakresie kierowania obradami sejmu wyrażał się G. Forster, op. cit., s. 79.

${ }^{42}$ I. Kurzeniecki, Mowa... w Izbie Poselskiej... 5 X 1784, [w:] Zbiór mów 1784, s. 12. Od swojego marszałka nie oczekiwali jednak specjalnych przywilejów, lecz tylko przestrzeganie prawa o sejmowaniu z 1768 r. Ibidem, s. 9-14.

${ }^{43}$ Sesja I dnia 4 X 1784, Diariusz sejmu 1784, s. 11.

${ }^{44}$ Sesja II dnia 5 X 1784, Diariusz sejmu 1784, s. 11-21.

${ }^{45}$ Sesje XI, XII i XIII dnia 15, 16 i 18 X 1784, Diariusz sejmu 1784, s. 47-51; S. Michalczew s ki, Przymówienie się... 18 X 1784..., [w:] Zbiór mów 1784, s. 21-24. 
potraktowania tej dyskusji za wtracanie się przedstawicieli Korony w wewnętrzne sprawy litewskie. Wiele więc miało zależeć od postawy i umiejętności politycznych Chomińskiego, który w dodatku musiał przestrzegać regulaminu obrad, nakazującego złożenie sprawozdań przez wszystkich deputowanych do oceny Komisji Skarbowej Litewskiej. Dlatego musiał wezwać do złożenia sprawozdań posłów: łomżyńskiego Floriana Drewnowskiego i krakowskiego Ignacego Dembińskiego, którzy podkreślili wady litewskiego systemu skarbowego jako zbyt sformalizowanego przy dochodzeniu należności, pozbawionego instrukcji celnej i uzupełnionych tabel wydatków skarbowych $^{46}$. Ten ciąg zarzutów spróbował marszałek Chomiński przerwać przedstawieniem tekstu explikacyi Antoniego Tyzenhauza na stawiane mu zarzuty ${ }^{47}$. W kolejnych sprawozdaniach deputatów nadal jednak dominowały oskarżenia o nieprawidłowości w pracach Komisji Skarbowej Litewskiej, które zadecydowały o odmowie udzielenia jej absolutorium przez dwa kolejne sejmy (w latach 1780 i 1782). Tu szczególnie szeroko zarzuty takie formułowali posłowie: sandomierski Stefan Dembowski (Dębowski), kijowski Józef Bierzyński, wieluński August Miączyński i znacznie bardziej ogólnikowo drohicki Jan Kuszel ${ }^{48}$. Takie oceny wywołały sprzeciw części posłów litewskich (wiłkomierskiego Józefa Kuszelewskiego i grodzieńskiego Stefana Popiela), podkreślających, że celem deputacji może być tylko zgłaszanie wątpliwości, których rozstrzygnięcie przysługuje jednak dopiero całej izbie. W dodatku deputowani zostali skrytykowani za podejmowanie spraw, które nie zostały im przedstawione do rozpatrzenia. W swoich zarzutach nie dostrzegli też bieżącego rozwiazywania przez Komisję Skarbową Litewska spraw celnych, oczekujących od dawna na uregulowanie. Przy okazji wezwali do uwolnienia powiatu grodzieńskiego od podatku pogłównego, wprowadzonego pod nieobecność jego posłów $^{49}$. Po tych ostrych wystapieniach kolejni mówcy (poseł inowrocławski Jan Paweł Wodziński, poseł oszmiański Michał Brzostowski, poseł sandomierski Wężyk) wnosili już tylko o okazanie

46 Ostatecznie jednak wzywali do udzielenia kwitu Komisji Skarbowej Litewskiej. Sesja XX dnia 23 X 1784, Diariusz sejmu 1784, s. 246-250.

${ }_{47}$ Zarzucono mu niszczenie inicjatywy kupieckiej, przywrócenie pańszczyzny i malwersacje, skutkiem których miało zginać 30000 zl, co tłumaczył pozbawieniem nadzoru nad dobrami królewskimi. Sesja XX dnia 23 X 1784, Diariusz sejmu 1784 , s. 250-257.

48 Sesja XX dnia 23 X 1784, Diariusz sejmu 1784, s. 262-278.

${ }^{49}$ Sesja XX dnia 23 X 1784, Diariusz sejmu 1784, s. 278-282. 
miłosierdzia podskarbiemu Tyzenhauzowi, zarzucając też deputacji posługiwanie się niepełnymi dokumentami ${ }^{50}$. Te głosy - odpowiadające dążeniom Chomińskiego - spotkały się ze sprzeciwem deputowanego Ignacego Dembińskiego, który żądał przerwania dyskusji, jak też posła brzeskolitewskiego Tadeusza Matuszewicza, uznającego wyjaśnienia podskarbiego Tyzenhauza za obraźliwe dla decyzji poprzednich sejmów, broniących interesów obywateli i skarbu państwa. $Z$ ich stanowiskiem nie zgodził się poseł brzeskolitewski Kazimierz Nestor Sapieha i zaapelował o miłosierdzie dla podskarbiego Tyzenhauza i jego kasjera Baranowicza, jako obywateli województwa brzeskolitewskiego ${ }^{51}$. Pozwoliło to marszałkowi Chomińskiemu na kolejnej sesji zakończyć tę dyskusję informacją o zakwitowaniu Komisji Skarbu Litewskiego. Ten sukces przypisał jednak królowi i jego decyzji o przywróceniu zasad alternaty sejmów. Miało to też otworzyć drogę do okazania litości dla podskarbiego Tyzenhauza, o która apelował monarcha w momencie rozdzielenia izb sejmowych ${ }^{52}$. Marszałek Chomiński zasygnalizował też możliwość podjęcia późniejszej dyskusji nad stanem armii litewskiej, której potrzeby przedstawiał w imieniu całej prowincji poseł piński Ignacy Kurzeniecki, powołując się też na memoriał K.N. Sapiehy do Departamentu Wojskowego o powiększenie artylerii Wielkiego Księstwa ${ }^{53}$.

Marszałek Chomiński zasadniczą rolę odgrywał jednak dopiero w czasie obrad w izbach rozłączonych, gdy już samodzielnie kierował obradami posłów i mógł w istotny sposób wpływać na wynik sporów między reprezentantami Litwy i Korony o zakres przywilejów obydwu prowincji. $Z$ reguły to reprezentanci WKL głosili pogląd o gorszym traktowaniu swojej prowincji, co właściwie jest zrozumiałe, chociaż nie w każdej kwestii uzasadnione, zwłaszcza w dziedzinie edukacji ${ }^{54}$. W 1784 r. wiele emocji wzbudziły zarzuty

50 Sesja XX dnia 23 X 1784, Diariusz sejmu 1784, s. 282-286. Por. W. Filipczak, Życie sejmikowe..., s. 575.

${ }^{51}$ Sesja XX dnia 23 X 1784, Diariusz sejmu 1784, s. 286-290.

52 Sesja XXI popołudniowa dnia 23 X 1784, Diariusz sejmu 1784, s. 291. Por. M. Drozdowski, Podstawy finansowe działalności państwowej $w$ Polsce 1764 1793. Działalność budżetowa Sejmu Rzeczypospolitej w czasach panowania Stanisława Augusta Poniatowskiego, Warszawa-Poznań 1975, s. 421-424.

${ }^{53}$ Sesja XVIII dnia 21 X 1784, Diariusz sejmu 1784, s. 162-192. Kurzeniecki przedstawił też wniosek o podniesienie uposażenia dowódców armii litewskiej.

${ }^{54}$ Litwini narzekali na utrudnienia w dostępie swojej młodzieży do edukacji i często występowali z wnioskami o tworzenie nowych szkół, jak w Słonimiu, o która zabiegał poseł Słonimski Michał Szwykowski. W rzeczywistości jednak, 
o utrzymywaniu w Warszawie większości urzędów, co miało powodować stały wypływ pieniędzy z Litwy, ubożejacej na skutek takiego podporzadkowania stolicy. Narzekano również na brak udziału prowincji litewskiej $\mathrm{w}$ dochodach $\mathrm{z}$ monopolu tabacznego oraz $z$ ceł i loterii ${ }^{55}$. Czasem występowano też przeciw rezolucjom Rady Nieustajacej odnoszacym się do Wielkiego Księstwa Litewskiego. Dla reprezentacji litewskiej najważniejsze było jednak poszanowanie postanowień unii lubelskiej, co wyrażało się w obronie zasad alternaty sejmów między Warszawa i Grodnem ${ }^{56}$, odrębnych władz i trybunałów ${ }^{57}$ bądź tylko w walce o wyższe miejsca w sena$\mathrm{cie}^{58}$. Tu trzeba zaznaczyć, że we wszystkich tych sprawach, tak żywo interesujacych reprezentację litewska, marszałek Chomiński zachowywał milczenie, włączajac się tylko w ciąg podziękowań dla Stanisława Augusta za zwołanie sejmu do Grodna ${ }^{59}$. Nigdy jednak nie przerywał takich wystąpień. Można nawet uznać, że w dostępie do możliwości zabrania głosu i wygłoszenia mowy posłowie litewscy byli przez marszałka Chomińskiego faworyzowani. Świadczyć o tym może liczba ich wystąpień zamieszczonych w Zbiorze mów z tego sejmu. O ile w 1778 r. - przypomnijmy: na sejmie „litewskim” - z odnotowanych 49 wystąpień zaledwie 12 przypadło na reprezentantów Litwy i Inflant (24,49\% ogółu), w 1780 r. z 262 mów na Litwę przypadło 62 (23,66\% ogółu), o tyle na sejmie grodzieńskim

mimo stale zgłaszanych pretensji, to właśnie prowincja litewska w najbliższych sejmowi grodzieńskiemu latach (1784/1785 i 1785/1786) zdołała zapewnić sobie 40\% miejsc w szkołach średnich Rzeczypospolitej (2490 wobec 3705 młodzieży koronnej). K. M rozows ka, By Polaków zrobić obywatelami, Kraków 1993, s. 73; M. Szwykow ski, Mowa... 25 X 1784, [w:] Zbiór mów 1784, s. 321-322.

${ }^{55}$ Diariusz sejmu 1784, s. 74; M. Szwy kow s ki, Mowa (...) 23 X 1784, [w:] Zbiór mów 1784, s. 221; S. Po piel, Mowa... 23 X 1784, [w:] Zbiór mów 1784, s. 117.

56 O narastaniu żądań litewskich, przed którymi ostatecznie musiał ustapić Stanisław August, por. A. Str oy now s ki, Sklikanne pershaga pry Stanislavu Ay̆gustu Panjatoy̆skim sojma..., s. 251-270; id e m, Problem odrębności litewskiej..., s. $125-141$.

57 Było to też wyrazem niechęci wobec centralizacyjnych dążeń Stanisława Augusta. Refleksja [Stanisława Lubomirskiego], Anexa do Dzienników i Pamiętników (...) Stanisława Lubomirskiego, AGAD, APP 313, t. XII, s. 247. Por. J. Malec, Próby ściślejszego zespolenia Litwy z Korona..., s. 167-186; J. Michalski, Zagadnienie unii polsko-litewskiej w czasie panowania Stanisława Augusta, „Zapiski Historyczne" 1986, t. LI, z. 1, s. 98-110; A. Stroy now ski, Opozycja sejmowa..., s. 309-310.

58 Taki spór stoczyli wojewodowie poznański i wileński (August Sułkowski i K.S. Radziwiłł). Sesja IV w senacie dnia 7 X 1784, Diariusz sejmu 1784, s. 29. Por. A. Stroynow s ki, Problem odrębności litewskiej..., s. 125-141.

${ }^{59}$ Sesja XXI popołudniowa dnia 23 X 1784, Diariusz sejmu 1784, s. 325-327. 
1784 r. reprezentacja litewska (z Inflantami) wygłosiła 19 z 47 mów $(40,43 \% \text { ogółu })^{60}$. Oczywiście taki wzrost aktywności oratorskiej reprezentacji litewskiej wynikał $z$ jej roli gospodarza obrad, chociaż niewątpliwie przyczyniała się do tego również postawa marszałka sejmu, reprezentującego Wielkie Księstwo Litewskie.

Od oratorskich popisów posłów i senatorów litewskich zdecydowanie ważniejszy był ustawodawczy dorobek tego sejmu, ostatecznie decydujący o ocenie korzyści $z$ alternaty grodzieńskiej. Pamiętajac o wskazanym już wyjątkowo pokaźnym dorobku ustawodawczym sejmu grodzieńskiego $1784 \mathrm{r} .{ }^{61}$, należy jednak zastanowić się nad liczbą przyjętych konstytucji, które odnosiły się tylko do prowincji litewskiej. Chyba tylko w ten sposób można będzie ocenić znaczenie alternaty sejmów dla Wielkiego Księstwa Litewskiego w epoce stanisławowskiej.

$Z$ analizy ustawodawstwa sejmu grodzieńskiego wynika, że aż 15 konstytucji - spośród 46 - odnosiło się do prowincji litewskiej i jej mieszkańców, co stanowi 32,6\% ogółu przyjętych ${ }^{62}$. Dla właściwej oceny takiego efektu należy dokonać porównania $z$ innymi sejmami zwyczajnymi w czasach stanisławowskich. Tu chyba najwłaściwsze jest zestawienie $z$ najbliższymi mu chronologicznie sejmami $z$ lat 1782 i 1786 . Na pierwszym $z$ nich, kierowanym przez Kazimierza Krasińskiego $z$ Małopolski, przyjęto 10 konstytucji, spośród których tylko jedna - czyli 10\% ogółu - odnosiła się wyłącznie do Litwy $^{63}$. Na sejmie 1786 r., kierowanym przez Stanisława Gadomskiego z Wielkopolski, przyjęto 32 konstytucje sejmowe, spośród których osiem - czyli 25\% - dotyczyło tylko Wielkiego Księstwa ${ }^{64}$. Do tego jednak można chyba doliczyć konstytucję Wzglad na zasługi narodu Tatarskiego, jako forsowana przez Kazimierza Nestora Sapiehę, chociaż częściowo odnoszącą się i do Korony ${ }^{65}$. Wskazuje

60 Zbiór mów 1778, nlb.; Diariusz sejmu 1780, s. 1-454; Zbiór mów 1784. Por. A. Stroy now ski, Problem odrębności litewskiej..., s. 125-141.

${ }^{61}$ W. Filipczak, Sejm Rzeczypospolitej $w$ dobie stanisławowskiej, s. 59-82; id e m, Uwagi o funkcjonowaniu "wolnych" sejmów..., s. 122; A. Stroynowski, Opozycja sejmowa..., s. 12; Z. Zielińska, Sejmy polskie z lat 1764-1786..., s. $113-114$.

62 Vol. leg., t. IX, s. 7-29.

${ }^{63}$ Osoby do Kommisyi skarbu W. X. Litt. ex prulalitate wybrane, [w:] Vol. leg., t. IX, s. 4.

64 Vol. leg., t. IX, s. 30-45.

${ }^{65}$ Vol. leg., t. IX, s. 40. Wówczas odsetek konstytucji „litewskich” wzrośnie do $28,1 \%$. Por. A. Stroynowski, Kazimierz Nestor Sapieha - talent parlamentar- 
to na dość znaczne różnice między tymi sejmami, chociaż z racji wyjątkowo niskiego dorobku ustawodawczego w 1782 r. porównywanie $z$ tym sejmem może być mylacce. W rezultacie ostateczna różnica w odsetku konstytucji litewskich jest już znacznie niższa, bo wahająca się między $32,6 \%$ (w 1784 r.) a $25 \%$ (w 1786 r.). Trudno więc mówić o zasadniczym przełomie, ale jest to różnica na tyle istotna, że potwierdza znaczenie zapewnienia prowincji litewskiej miejsca obrad sejmowych i wyboru swojego marszałka. Od miejsca obrad ważniejsze znaczenie miało chyba sprawowanie funkcji marszałka sejmowego przez reprezentanta Litwy. Przeczyć temu jednak moga doświadczenia warszawskiego sejmu 1778 r., teoretycznie litewskiego, którego marszałek poseł wileński Ludwik Tyszkiewicz w niewielkim tylko stopniu angażował się w obronę interesów Litwy, co wyraziło się przyjęciem zaledwie pięciu ( $z$ 32, czyli $15,6 \%$ ) konstytucji odnoszacych się wyłącznie do Litwy lub jej

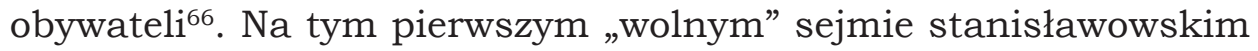
skupiono się jednak głównie na sprawach ustrojowych, po części zapominając o sprawach lokalnych, co zresztą zgodne było z planami króla, realizowanymi przez męża jego bratanicy ${ }^{67}$.

O znaczeniu miejsca obrad sejmowych dla zapewnienia korzyści swojej prowincji decydowała nie tyle liczba, co charakter konstytucji sejmowych. Wynika to wyraźnie $z$ dorobku ustawodawczego sejmu grodzieńskiego 1784 r. Wśród przyjętych wówczas konstytucji „litewskich” - obok mających tylko porządkowe znaczenie ${ }^{68}$ - znalazło się bowiem pomyślne rozwiązanie problemu rozliczenia Komisji Skarbowej Litewskiej, która nie mogła uzyskać absolutorium na poprzednich sejmach ${ }^{69}$. Ściśle powiązana $z$ tą kwestią

ny XVIII wieku, [w:] Historia na źródłach oparta. Studia ofiarowane Profesorowi Tadeuszowi Srogoszowi na 65 rocznice urodzin, red. A. Stroynowski, Częstochowa 2017, s. 690.

66 Vol. leg., t. VIII, Petersburg 1860, s. 575-581.

${ }^{67}$ W. Filipczak, Sejm 1778 roku..., s. 40-41, 144-145, 335; Anegdoty $i$ sensacje obyczajowe..., s. 30, 291.

68 Taki charakter miały konstytucje: 1 . Osoby do kommisyi skarbu W. X. Litt; 2. zalecenie skarbowi W. Xstwa Litt (przeznaczenie dodatkowych środków na potrzeby wojska litewskiego); 3. przyjęcie ofiary U. Kazimierza Sapiehy; 4. uspokojenie długu J. W. wojewodzie wileńskiemu; 5. zwrócenie prerogatywy podkomorstwa nowogródzkiego dla sukcesorów U. Jana Niezabitowskiego. Vol. leg., t. IX, s. 7-29.

${ }^{69}$ Kwit dla Komisji Skarbu Lit, Vol. leg., t. IX, s. 13. Sprawa ta ciagnęła się od 1778 r. i chociaż miała formalnie podstawy czysto finansowe, to faktycznie stanowiła element walki politycznej na Litwie. S. Kościałkowski, Antoni Tyzen- 
była również konstytucja Uspokojenie interesu Skarbu Litewskiego, w której podtrzymano decyzję sądu z 1780 r., nakazującą Antoniemu Tyzenhauzowi spłatę wszystkich zobowiązan wobec skarbu litewskiego, po uiszczeniu których dopiero mogło nastapić zwrócenie mu zajętych dóbr. Jednocześnie zapewniono podskarbiemu prawo dochodzenia tych sum od swoich byłych urzędników (Andrzejkowicza, Zdzitowieckiego, Orzeszki i Czyża), ponoszących główną winę za powstałe niedobory, ale jednak uwolnionych od dodatkowych $\operatorname{kar}^{70}$.

Bardzo istotne znaczenie miały również trzy konstytucje odnoszące się do zasad funkcjonowania sądownictwa w Wielkim Księstwie Litewskim, co wiązało się $z$ szerszym podjęciem przez ten sejm tych kwestii. Ważne było wprowadzenie jasnych zasad rejestrowania wszelkich wyroków wydawanych przez sądy litewskie (od trybunału zaczynajac) i kierowania wniosków o ich egzekucje wojskowa ${ }^{71}$. Szczególnie potraktowana została kwestia ustalenia zasad składania manifestów i remanifestów, w których podkreślono obowiazek pełnego przedstawienia istoty sporu ${ }^{72}$. Uporzadkowano również zasady rejestrowania spraw wnoszonych do Trybunału Litewskiego przez wprowadzenie zakazu łączenia w pozwie różnych rodzajów spraw ${ }^{73}$. Podobnie unormowano funkcjonowanie trybunału duchownego litewskiego, gdzie odwołując się do postanowień konstytucji z 1726 i 1764 r., zakazano wnoszenia innych spraw niż tylko odnoszących się do duchowieństwa ${ }^{74}$. Należy przy tym zaznaczyć, że również w obejmujących całą Rzeczypospolitą konstytucjach, regulujących funkcjonowanie sądów i sądowych procedur, stale zaznaczana była konieczność zaznaczania litewskiej odrębności i przestrzegania praw obywateli Wielkiego Księstwa Litewskiego $^{75}$.

hauz. Podskarbi nadworny litewski, t. II, Londyn 1971, s. 175, 362-363; id e m, $Z$ dziejów Komisji Skarbowej litewskiej w poczatkach panowania Stanisława Augusta (1764-1780), „Ateneum Wileńskie” 1924, R. II, s. 371-408; M. D r o zd ow s ki, op. cit.; W. Filipczak, Kontrola Komisji Skarbu Litewskiego na sejmie z 1778 roku, „Acta Universitatis Lodziensis”, Folia Historica 67, 2000, s. 181-199.

70 Uspokojenie interesu Skarbu Litewskiego, Vol. leg., t. IX, s. 12-13.

${ }^{71}$ Warunek dla Wielkiego Xięstwa Litewskiego, Vol. leg., t. IX, s. 19.

72 Proces sadowy w WKL. Manifesta i remanifesta, Vol. leg., t. IX, s. 19-20.

73 Trybunał główny WKL koła ziemskiego, Vol. leg., t. IX, 21-22.

74 Trybunał duchowny WKL, Vol. leg., t. IX, s. 22.

75 Najpełniej ta dbałość o te interesy występuje w konstytucjach: 1. przystosowanie resztujacey ustawy do dekretów executionis; 2. kadencyow sądowych 
Mniejsze znaczenie, chociaż poprzedzone ostrą dyskusją, miała konstytucja regulujaca wynagrodzenie marszałka wielkiego litewskiego Władysława Gurowskiego. Jego pensję zrównano (od 1784 r.) $z$ wynagrodzeniem marszałków i hetmanów koronnych, ale odrzucono żądanie Gurowskiego naliczania jej od $1774 \mathrm{r}^{76}$ Podobnie szerokie zainteresowanie reprezentacji litewskiej budziła sprawa ratyfikacja konwencji handlowej $z$ Kurlandia, chociaż formalnie konstytucja w tej sprawie odnosiła się do całego państwa ${ }^{77}$. Praktycznie bez dyskusji natomiast przyjęto konstytucje w mniej istotnych sprawach. W jednej $z$ nich zmieniono liczbę i terminy kadencji sądowych dla powiatów wołkowyskiego i brasławskiego ${ }^{78}$. W drugiej zaś uchylono rezolucję Rady Nieustającej o opatach bazyliańskich jako sprzeczna $z$ prawem $1768 \mathrm{r}^{79}$

Konkludujacc te rozważania, oparte na analizie przebiegu obrad i dorobku ustawodawczego sejmu grodzieńskiego 1784 r., należy stwierdzić, że sprawa alternaty była nie tylko kwestia czysto ambicjonalna czy też jedynie prawniczym traktowaniem zapisów unii lubelskiej. Okazuje się, że alternata sejmów między Warszawą a Grodnem miała rzeczywiste znaczenie dla społeczeństwa Wielkiego Księstwa Litewskiego. Składało się na to kilka czynników. Najbardziej widoczna korzyścia stało się wymuszenie na królu Stanisławie Auguście uznania równorzędności Korony i Litwy, do której musiał wreszcie odbyć swoją podróż, pierwszą w ciagu jego panowania. Po drugie, musiał zbliżyć się do magnatów i czołowych przedstawicieli szlachty litewskiej, spośród której wyłoniony też został marszałek sejmu Franciszek Ksawery Chomiński. W trakcie samych obrad reprezentacja litewska uzyskała też pewne przywileje w postaci szerszego dostępu do możliwości udziału w dyskusji

ubezpieczenie; 3. sessye sądowe; 4. inkwizycje, kalkulacje, i weryfikacje, Vol. leg., t. IX, s. 19-21.

${ }^{76}$ Warunek dla Skarbu WKL, Vol. leg., t. IX, s. 13-14. Dyskusja w tej sprawie toczyła się szczególnie na sesjach: XXVI dnia 29 X 1784, XXIX dnia 3 XI 1784, XXXII dnia 6 XI 1784 i XXXIII dnia 8 XI 1784, Diariusz sejmu 1784, s. 404-408, 482-496, 528-531, 532-533.

77 Ratyfikacya konwencyi handlowey i graniczney przez kommisarzow Nayjaśnieyszey Imperatorowey całej Rossy, i Księstw Kurlandyi i Semigallii zawartey, tudzież aktu przystapienia powiatu Piltyńskiego do teyże konwencji, Vol. leg., t. IX, s. 23.

78 Sądy grodzkie i ziemskie województwa trockiego, Vol. leg., t. IX, s. 23.

${ }^{79}$ Uchylenie rezolucji Rady Nieustającej z 14 III 1783 o opatach bazyliańskich, Vol. leg., t. IX, s. 10. 
i budowania podstaw osobistej popularności, co oznaczało także większy wpływ na kształt podejmowanych decyzji. Ostatecznym efektem tego stało się przyjęcie w trakcie sejmu grodzieńskiego aż 15 (spośród 46) konstytucji odnoszacych się wyłącznie do Litwy i jej mieszkańców, co stanowi 32,6\% ogółu przyjętych. Prócz tego przynajmniej w czterech dalszych konstytucjach odnoszacych się do procedur sądowych szczegółowo zabezpieczono interesy litewskie, co oznacza możliwość podniesienia tego odsetka nawet do ponad $41 \%$, chociaż nie jest to już tak istotne. W rezultacie należy uznać, że przestrzeganie zasady alternaty sejmów miało dla społeczeństwa Wielkiego Księstwa Litewskiego rzeczywiście duże znaczenie i dlatego zrozumiałe jest stałe dążenie reprezentacji litewskiej do przywrócenia tej zasady, opartej na unii lubelskiej.

\section{Bibliografia}

\section{Źródea ARChIWALNE}

Archiwum Główne Akt Dawnych w Warszawie [AGAD]

Archiwum Królestwa Polskiego [AKP], 268.

Archiwum Publiczne Potockich [APP], 310, 313, t. XII.

Archiwym Radziwiłłowskie [AR], V/13850.

Tzw. Metryka Litewska [ML], VII/52.

Biblioteka Czartoryskich w Krakowie [B. Czart.]

rkps 661, 726.

Biblioteka Jagiellońska w Krakowie [BJ]

rkps 6666.

Biblioteka Kórnicka PAN [BKPAN]

rkps 1330, 1331.

Biblioteka Polskiej Akademii Nauk w Krakowie [B. PAN] rkps 993.

\section{$\dot{\mathbf{Z}}_{\text {RÓDEA DRUKOWANE }}$}

Anegdoty $i$ sensacje obyczajowe wieku Oświecenia $w$ Polsce. Dokumenty, wspomnienia, facecje, zebrał i oprac. R. Kaleta, Warszawa 1958.

Coxe W., Podróż po Polsce, [w:] Polska stanisławowska w oczach cudzoziemców, oprac. W. Zawadzki, t. I, Warszawa 1963, s. 559-703.

Dyariusz sejmu wolnego ordynaryjnego grodzieńskiego sześcioniedzielnego Roku Pańskiego MDCCLXXXIV dnia 4 miesiaca października odprawującego się, [wyd. M. Tukalski-Nielubowicz], Warszawa 1785. 
Dyaryusz sejmu wolnego ordynaryjnego warszawskiego sześcioniedzielnego Roku Pańskiego MDCCLXXX dnia 2 miesiaca października odprawuiacego się, [wyd. S. Badeni], Warszawa [1780].

Dyaryusz sejmu wolnego ordynaryjnego warszawskiego sześcioniedzielnego Roku Pańskiego MDCCLXXXII, [P. Kicińskiego], [Warszawa 1782].

Dyaryusz tygodniowy sejmu... MDCCLXXXIV, b.m.d.

Forster G., Dziennik podróży po Polsce, [w:] Polska stanisławowska w oczach cudzoziemców, oprac. W. Zawadzki, t. II, Warszawa 1963, s. 41-103.

[Naruszewicz A.], Dyaryusz podróży... Stanisława Augusta na Seym Grodzieński..., Warszawa 1784.

Naruszewicz A.S., Dyjaryjusz podróży Jego Królewskiej Mości na sejm grodzieński, wyd. M. Bober-Jankowska, Warszawa 2008.

Niemcewicz J.U., Pamiętniki czasów moich, wyd. J. Dihm, t. I, Warszawa 1957.

Propozycje od tronu... na sejm 1784, b.m.d.

Sievers J.J., Drugi rozbiór Polski z pamiętników, Poznań 1865.

Stanisław August Poniatowski, Pamiętniki, oprac. Z. Góralski, t. I, Warszawa 1994.

Volumina legum. Przedruk Zbioru Praw, t. VIII, Petersburg 1860.

Volumina legum. Wyd. Komisji Prawniczej AU w Krakowie, t. IX, Kraków 1889.

Zagadki Sejmu Czteroletniego, zebrał E. Rabowicz, oprac. B. Krakowski, E. Rabowicz, wyd. J. Kowecki, Warszawa 1996.

Zaleski B., Korespondencja krajowa Stanisława Augusta z lat 1784 do 1792, Poznań 1872.

Zbiór mów różnych $w$ czasie sejmu ostatniego sześcioniedzielnego roku 1778 mianych, Wilno [1778], nlb.

Zbiór mów różnych $w$ czasie sejmu sześcioniedzielnego sejmu roku 1782 mianych, Wilno [1782].

Zbiór mów w czasie sejmu sześcioniedzielnego roku 1784 mianych $w$ Grodnie, Wilno [po XI 1784].

\section{OpRacowania}

Anusik Z., Stroynowski A., Problemy majatkowe Radziwiłłów w XVIII w., „Roczniki Dziejów Społecznych i Gospodarczych" 1987, t. XLVIII, s. 79-115.

Bardach J., Konstytucja 3 Maja i Zaręczenie Wzajemne Obojga Narodów 1791 roku, [w:] Konstytucja 3 Maja 1791, Warszawa 2001, s. 5-56.

Bardach J., O Rzeczpospolita Obojga Narodów. Dzieje zwiazku Polski z Litwa do schyłku XVIII wieku, Warszawa 1998.

Bartoszewicz K., Radziwiłłowie, Warszawa-Kraków 1927.

Drozdowski M., Podstawy finansowe działalności państwowej w Polsce 1764 1793. Działalność budżetowa Sejmu Rzeczypospolitej w czasach panowania Stanisława Augusta Poniatowskiego, Warszawa-Poznań 1975.

Dunin-Wilczyński Z., Order Św. Stanisława, Warszawa 2006. 
Filipczak W., Kontrola Komisji Skarbu Litewskiego na sejmie z 1778 roku, „Acta Universitatis Lodziensis", Folia Historica 67, 2000, s. 181-199.

Filipczak W., Sejm 1778 roku, Warszawa 2000.

Filipczak W., Sejm Rzeczypospolitej $w$ dobie stanisławowskiej, [w:] Między konstytucja Nihil Novi a ustawodawstwem nowoczesnej demokracji. Parlamentaryzm polski XVI-XX wieku. Materiały Ogólnopolskiej Konferencji Naukowej odbytej $w$ Radomiu $w$ dniach 12-13 października 2005 roku, red. H. Gmiterek, S. Piątkowski, J. Wrona, Radom 2005, s. 59-82.

Filipczak W., Uwagi o funkcjonowaniu „wolnych” sejmów okresu Rady Nieustajacej (1778-1786), [w:] Parlamentaryzm w Polsce we współczesnej historiografii, red. J. Bardach, W. Sudnik, Warszawa 1995, s. 107-126.

Filipczak W., Życie sejmikowe prowincji wielkopolskiej w latach 1780-1786, Łódź 2012.

Gordziejew J., Socjotopografia Grodna w XVIII wieku, Toruń 2009.

Grodziski S., Sejm dawnej Rzeczypospolitej jako najwyższy organ ustawodawczy. Konstytucje sejmowe - pojęcia i próba systematyki, „Czasopismo Prawno-Historyczne" 1983, t. XXXV, z. 1, s. 163-175.

Historia dyplomacji polskiej, t. II (1572-1795), red. Z. Wójcik, Warszawa 1982.

Historia sejmu polskiego, t. I (Do schyłku Rzeczypospolitej), red. J. Michalski, Warszawa 1984.

Iwaszkiewicz J., Z dziejów wielkiej fortuny, „Biblioteka Warszawska” 1911, R. IV, s. 479-501.

Kalenkiewiczówna A., Rozkład partii Tyzenhauza na tle sejmików litewskich, [w:] Ksiega pamiątkowa Koła Historyków Słuchaczy Uniwersytetu Stefana Batorego w Wilnie 1923-1933, Wilno 1933, s. 152-186.

Kalinka W., Sejm Czteroletni, t. I, Kraków 1895.

Konopczyński W., Chomiński Franciszek Ksawery, [w:] Polski słownik biograficzny, t. III, Kraków 1937, s. 416-417.

Konopczyński W., Chronologia sejmów polskich 1493-1793, Kraków 1948.

Konopczyński W., Fryderyk Wielki a Polska, Poznań 1947.

Kościałkowski S., Antoni Tyzenhauz. Podskarbi nadworny litewski, t. II, Londyn 1971.

Kościałkowski S., $Z$ dziejów Komisji Skarbowej litewskiej w początkach panowania Stanisława Augusta (1764-1780), „Ateneum Wileńskie” 1924, R. II, s. 371-408.

Kriegseisen W., Sejm Rzeczypospolitej szlacheckiej (do 1763 roku). Geneza i kryzys władzy ustawodawczej, Warszawa 1995.

Lityński A., Sejmiki ziemskie 1764-1793, Katowice 1988

Łaszewski R., Pozycja sejmików przedsejmowych $w$ systemie politycznym Polski stanisławowskiej, [w:] Ustrój i prawo w przeszłości dalszej i bliższej. Studia o prawie dedykowane Prof. Stanisławowi Grodziskiemu w pięćdziesiąta rocznice pracy naukowej, red. J. Malec, W. Uruszczak, Kraków 2001, s. 139-144.

Łaszewski R., Sejm polski $w$ latach 1764-1793. Studium historyczno-prawne, Warszawa 1973. 
Malec J., Próby ściślejszego zespolenia Litwy z Korona w latach 1764-1786, „Lituano-Slavica Posnaniensia. Studia Historia" 1987, t. II, s. 167-185.

Malec J., Szkice $z$ dziejów federalizmu i myśli federalistycznej $w$ czasach nowożytnych, Kraków 1999.

Matwijowski K., Sejm grodzieński 1678-1679, Wrocław 1985

Michalski J., Lubomirski Stanisław, [w:] Polski słownik biograficzny, t. XVIII, Wrocław 1973, s. 53-56.

Michalski J., Poniatowski Stanisław, [w:] Polski słownik biograficzny, t. XXVII, Wrocław 1982, s. 481-487.

Michalski J., Radziwiłł Karol Stanisław, [w:] Polski słownik biograficzny, t. XXX, Wrocław 1987, s. 248-262.

Michalski J., Sprawa przymierza polsko-rosyjskiego $w$ dobie aneksji Krymu, [w:] idem, Studia historyczne z XVIII i XIX wieku, t. I (Polityka i społeczeństwo), Warszawa 2007, s. 420-448.

Michalski J., Zagadnienie unii polsko-litewskiej $w$ czasie panowania Stanisława Augusta, „Zapiski Historyczne” 1986, t. LI, z. 1, s. 98-110.

Mrozowska K., By Polaków zrobić obywatelami, Kraków 1993.

Mycielski J., Ksiażę „Panie Kochanku” w świetle własnej korespondencji, Petersburg 1989.

Olszewski H., Wstęp, [do:] Marszałkowie sejmów I Rzeczypospolitej, oprac. W. Sieradzki, J. Kotowicz, J. Walukiewicz-Wolfram, Warszawa 1993, s. 5-23.

Rachuba A., Litewscy marszałkowie sejmów Rzeczypospolitej (1569-1793), [w:] Kultura parlamentarna epoki staropolskiej. Studia pod redakcja Andrzeja Stroynowskiego, Warszawa 2012, s. 33-47.

Rolnik D., Miejsce i rola Radziwiłłów $w$ życiu publicznym Rzeczypospolitej lat 1764-1795 w świetle literatury pamiętnikarskiej czasów stanisławowskich, [w:] Radziwiłłowie. Biografie. Swiadectwa historyczne, red. K. Stępnik, Lublin 2003, s. 385-402.

Rosner A., Mniszech Michał Jerzy Wandalin, [w:] Polski słownik biograficzny, t. XXI, Wrocław 1976, s. 480-484.

Rostworowski E., Potocki Stanisław Szczęsny, [w:] Polski słownik biograficzny, t. XXVIII, Wrocław 1984, s. 183-202.

Skałkowski A., Stanisław Kostka Bielinski, [w:] Polski słownik biograficzny, t. II, Kraków 1936, s. 56-57.

Słownik Geograficzny Królestwa Polskiego i innych krajów słowiańskich, red. F. Sulimierski, B. Chlebowski, W. Walewski, t. II, Warszawa 1881, s. 831 (hasło: Grodno).

Srogosz T., Dywizja ukrainska i podolska wobec wkroczenia armii rosyjskiej do Rzeczypospolitej w 1783 roku, „Naukovi praci istorichnogo fakultetu Zaporizkogo nacionalnogo universitetu" 2009, Vipusk 26, s. 133-137.

Srogosz T., Rzeczpospolita wobec aneksji Krymu przez Rosje w 1783 roku, [w:] Władza i polityka w czasach nowożytnych, red. Z. Anusik, Łódź 2011, s. 77-96.

Stroynowski A., Elita polityczna Wielkopolski w epoce stanisławowskiej, [w:] Spojrzenia na pogranicze dawniej $i$ dziś. Budowanie tożsamości na pograniczach, red. B. Burda. M. Szymczak, cz. 1, Zielona Góra 2009, s. 70-84. 
Stroynowski A., Kazimierz Nestor Sapieha - talent parlamentarny XVIII wieku, [w:] Historia na źródłach oparta. Studia ofiarowane Profesorowi Tadeuszowi Srogoszowi na 65 rocznice urodzin, red. A. Stroynowski, Częstochowa 2017, s. 681-696.

Stroynowski A., Opozycja sejmowa $w$ dobie rządów Rady Nieustającej: studium z dziejów kultury politycznej, Łódź 2005.

Stroynowski A., Patriotyczne wystapienia opozycji na sejmie 1778 r., „Acta Universitatis Lodziensis", Folia Historica 19, 1984, s. 173-180.

Stroynowski A., Poset - reprezentant narodu, czy regionu? Ujecie historyczne, [w:] Oblicze polityczne regionów Polski. Elity i społeczeństwo, red. M. Dajnowicz, Białystok 2008, s. 237-251.

Stroynowski A., Postawy polityczne elit Wielkopolski w epoce stanisławowskiej (województwa poznańskie, kaliskie i gnieźnieńskie), [w:] Między barokiem a oświeceniem. Staropolski regionalizm, red. S. Achremczyk, Olsztyn 2008, s. 203-214.

Stroynowski A., Problem odrębności litewskiej w obradach sejmów lat 1778-1786, [w:] Rzeczpospolita państwem wielu narodowości $i$ wyznań XVI-XVIII wiek, red. T. Ciesielski, A. Filipczak-Kocur, Warszawa-Opole 2008, s. 125-141.

Stroynowski A., Przeprowadzenie spłaty długów królewskich na sejmie 1784 roku, [w:] Sic erat in votes. Studia i szkice ofiarowane Profesorowi Zbigniewowi Anusikowi $w$ sześćdziesiąta rocznice urodzin. Rzeczpospolita $w$ czasach nowożytnych, red. M. Karkocha, P. Robak, Łódź 2017, s. 363-383.

Stroynowski A., Sklikanne pershaga pry Stanislavu Ay̆gustu Panjatoy̆skim sojma y̆ Goradni y̆ 1784 godze, „Arche”, Garadzenski milenium 2014, № 11, s. 251-274.

Stroynowski A., Sojm u Gorodni y̆ 1784 g. Ab'jawnanyja pasjadżenni palat 6-23 kastrychnika 1784 g., „Arche”, Garadskaja gistoryja Belarusi 2017, № 2 (152), s. 199-224.

Stroynowski A., Wpływ marszałków na obrady sejmów stanisławowskich, [w:] idem, „Wieczory sejmowe”. Studia nad dziejami parlamentaryzmu w epoce stanisławowskiej, Częstochowa 2013, s. 103-118.

Stroynowski A., Zmiany sytuacji politycznej $w$ Rzeczypospolitej przed ostatnim „wolnym” sejmem w 1786 r., „Acta Universitatis Lodziensis”, Folia Historica 58, 1996, s. 83-102.

Zakrzewski A.B., Paradoksy unifikacji prawa i ustroju Wielkiego Ksiesstwa Litewskiego i Korony XVI-XVIII w., "Czasopismo Prawno-Historyczne” 1999, t. LI, z. 1, s. 219-238.

Zielińska Z., Poniatowski Michał Jerzy, [w:] Polski słownik biograficzny, t. XXVII, Wrocław 1982, s. 455-471.

Zielińska Z., Sejmy polskie z lat 1764-1786, [w:] Parlamentaryzm $w$ Polsce we współczesnej historiografii, red. J. Bardach, W. Sudnik, Warszawa 1995, s. 107-116.

Zielińska Z., Sosnowski Józef Sylwester, [w:] Polski słownik biograficzny, t. XL, Warszawa-Kraków 2001, s. 559-563. 